\title{
WHY REORGANIZATION OF FIRMS FAILS: EVIDENCE FROM ESTONIA
}

\author{
Oliver Lukason, Artjom Urbanik ${ }^{1}$ \\ University of Tartu
}

\begin{abstract}
Although most countries have firm reorganization option in legislation (either as a separate law or part of insolvency code), the practice of successful reorganizations has remained modest. Reorganization law was introduced in Estonia in late 2008, but only a few firms have been successfully reorganized since. Derived from previous the article studies, what are the reasons for firm reorganization failure. From legal viewpoint, main causes are found to be that firms under reorganization do not submit reorganization plans to court and the preconditions for reorganization lapse. The financial ratios for successful and unsuccessful reorganizations are not significantly different according to independent samples median test. Unsuccessfully reorganized firms perform worse than successful ones in the year before reorganization year, but the opposite phenomenon occurs two and three years before reorganization year.
\end{abstract}

Keywords: firm reorganization, firm failure, reorganization law

JEL Classification: G33, G34, K22

\section{Introduction}

In majority of world countries, firm reorganization option, either through a separate law or integrated into insolvency code, is available in legal system. In 2000s, especially during the years characterized by thorough crisis, the necessity of having efficient legal procedures to overcome difficulties became increasingly important in business environment. One of the key challenges of economic policy and regulations created to achieve its objectives is to guarantee that productive and competitive firms should remain functioning, at the same time cleaning market quickly and efficiently of failed firms. Still, the problem exists that insolvency legislation can delay the movement of resources towards uses maximizing their value (White 1989). The importance of the issue has also been outlined in the European Union level as insolvency resolution systems of several member states have been rather inefficient (see e.g. Bankruptcy ... 2002). Despite the introduction or improvement of reorganization procedures in various countries, majority of firms where

\footnotetext{
${ }^{1}$ Oliver Lukason, Research Fellow, University of Tartu, Faculty of Economics and Business Administration, Narva Road 4-A307, Tartu 51009, Estonia. E-mail: oliver.lukason@ut.ee.

Artjom Urbanik, Tartu University Economics and Business Administration master's program graduate from year 2012.

The study has been prepared with financial support received from Estonian Ministry of Education and Research funding SF0180037s08.
} 
reorganization was started, still become bankrupt (see e.g. Couwenberg 2001), bringing to the question why such phenomenon occurs.

The practice of successful reorganisations in Estonia has been modest compared to petitions filed. According to court statistics (I ja II astme ... 2010) during year 2009 there were 93 reorganization petitions submitted to county courts in Estonia (compared to 1562 bankruptcy petitions), but only 6 of them resulted in the approval of reorganization plan, but this of course does not guarantee the successful implementation of approved plans during the reorganization process. One possible reason can be that problems have developed too far for firm and the reorganization process should have been started much earlier.

Derived from previous, the objective of current article is to find out the reasons why reorganization has failed on the example of Estonian firms. The objective will be achieved in two different domains. Firstly, the reorganization failure reasons will be brought out using the classification given in legislation. Secondly, financial indicators of successfully reorganized firms will be compared with those of unsuccessful reorganizations, to find out whether given two groups of firms differ. The article is structured in a classical way. After the introductory part, a short overview of most important results from previous studies focusing on reorganization will be outlined. This is followed by the description of Estonian reorganization law, mainly focusing on the possibilities set in law how the reorganization can become unsuccessful. Given section is followed by the empirical analysis in two domains mentioned under the objective of article. The article ends with conclusive remarks and implications.

\section{Previous research about failed firm reorganization}

Firm reorganization has received a lot of attention in research of past years, various facets of it being studied. Studies have shown high variance in both, the share of firms applying for reorganization procedure and the positive outcomes from that (see e.g. Couwenberg 2001). United States is often characterized by more positive reorganization outcomes when compared with other countries (Couwenberg 2001, Brouwer 2006). Still, results are highly dependent of datasets used and different periods of economic activity can show highly diverging results also. In addition, it is important to follow whether successful reorganization is considered to be the approval of reorganization plan by creditors, successful implementation of given plan or final survival of firm after the plan has been carried out.

In most general terms more (successful) reorganizations in the United States could be connected to the debtor friendliness of insolvency legislation, when at the same time (Continental-) European systems are considered to favor more creditor (see e.g. Franks et al. 1996, Lopez Gutierrez et al. 2011). Claessens and Klapper (2005) found on the example of 35 countries that higher judicial efficiency leads to increased use of bankruptcy, but stronger creditor rights in turn decrease the use of that. Still, as studies by Kaiser (1996), Davydenko and Franks (2008), Djankov et al. 
(2008), Wang (2012) show, the evidence on the specific impact of legal environment on the aplication and outcomes of reorganization still remains mixed.

When coming to firm specific factors, failed reorganization is often connected with failed turnaround (Chowdhury 2002, Sheppard and Chowdhury 2005). Failed reorganizations are linked to wrong timing of turnaround and wrong turnaround activities to overcome problems, namely firms tend to start reorganization at a too late stage and deal more with operational problems rather than initiating strategic reorientation (Chowdhury 2002, Sudarsanam and Lai 2001, Barker III and Duhaime 1997).

Several studies also consider the suitability of firms for reorganization and also the success of reorganization based on past financial ratios. Laitinen (2011) showed that most firms under reorganization are not viable. Also, evidence has been provided that financial ratios might not be good discriminators of successful and failed reorganizations (Poston et al. 1994, Laitinen 2009). Unsuccessful reorganizations can be connected with different financial patterns, as it has been shown that firms go through different failure processes (Laitinen 1991, Lukason 2012). Still, at least some financial indicators are very poor in case of unsuccessfully reorganized firms (Kärkinen 2010).

In Estonia no academic research was found about the causes of firm reorganization failure, although an applied study composed in the Supreme Court of Estonia by Vutt (2011) outlines some reasons of reorganization failure. The roots of the causes of unsuccessful reorganizations could also be derived from Lukason (2010) applied study focusing on all Estonian bankruptcies in 2000s, where it was concluded that most firms are in very poor financial health before bankruptcy is declared.

\section{Estonian reorganization law}

The Estonian Reorganization Law (afterwards $E R L$ ) entered into force in 26. December 2008, about 14 years later than the Estonian Bankruptcy Act (afterwards $E B A$ ). The law has been changed at two points of time, namely the amendments have entered into force in 22. January 2010 and 1. June 2012. Still, named changes have altered only one section of a paragraph describing the scope of application of the law, so for a private or public limited firm being governed by the Estonian Business Code (afterwards $E B C$ ) no changes have occurred since the first wording of law. Before 26. December 2008 reorganization was possible under EBA, but its practice was almost nonexistent.

As current article focuses on unsuccessful reorganization, the following description of law emphasizes the options in case of which reorganization of firm can fail. Reorganization process is governed by county court by appointing at least one reorganization advisor. Initially, court might decide not to open reorganization proceedings at all. This can in turn be the results of various reasons. Firstly, the reorganization petition must meet the requirements set in different laws. Secondly, it must be motivated that firm's insolvency in the future is likely, it needs 
reorganization and the sustainable management of firm is possible in the future (ERL $\S 8)$. Given principles in ERL $\S 8$ clearly indicate that a firm which is already permanently insolvent or will become one no matter of the activities taken to restore its vitality, is not suitable for reorganization procedure.

When reorganization proceedings have been started, then ERL $\$ 38$ gives that they can come to an end in case of premature termination, revocation of reorganization plan, premature completion of reorganization plan or when the reorganization plan completion date is exceeded. Out of those four general possibilities only one (i.e. premature completion of reorganization plan) symbolizes successful reorganization and all other point to some type of failure. Followingly, the options under given failure categories will be considered in more detail.

ERL §39(2) gives 10 different options in case of which premature termination of reorganization can occur. They are:

1. When entrepreneur violates cooperation obligation (ERL §14), i.e. firm's management does not provide necessary help and information for reorganization proceedings. (i.e. $\$ 39(2)((1)))$

2. When entrepreneur does not pay funds set by court and meant to finance reorganization advisor(s) and experts to court deposit (ERL $§ 18$ and §30). (i.e. $\S 39(2)((2)))$

3. When reorganization plan is not approved by creditors (ERL §28). (i.e. $\S 39(2)((3)))$

4. When the application for the approval of reorganization plan unapproved by creditors is not satisfied (ERL §30). (i.e. §39(2)((4)))

5. When the reorganization plan unapproved by creditors is not approved (ERL $\S 37)$. (i.e. $\S 39(2)((5)))$

6. When entrepreneur itself applies it (ERL §40). (i.e. $\$ 39(2)((6)))$

7. When the preconditions to start reorganization proceedings lapse (ERL $\$ 40)$. (i.e. $\S 39(2)((7)))$

8. When firm's property is squandered or the interests of creditors are damaged (ERL §41). (i.e. §39(2)((8)))

9. When reorganization plan is not submitted for the date set by court (ERL §42). (i.e. $\$ 39(2)((9)))$

10. When the claim is not clear (ERL §43). (i.e. $§ 39(2)((10)))$

Previous list described situations when reorganization proceedings have been started, but the process does not come to the point where entrepreneur can start acting according to approved plan. Reorganization can fail also after the approval of reorganization plan, namely there are seven different possibilities (ERL §51(1)):

1. When entrepreneur will be convicted of bankruptcy or execution proceeding crime. (i.e. $\$ 51(1)((1)))$

2. When entrepreneur does not fulfill obligations set in reorganization plan to a significant extent. (i.e. $\$ 51(1)((2)))$

3. When after at least half of the reorganization plan implementation time has passed and it becomes clear that entrepreneur is not able fulfill obligations set in reorganization plan. (i.e. $\$ 51(1)((3))$ ) 
4. When reorganization advisor presents an application that it has not been paid its fee. (i.e. $\$ 51(1)((4)))$

5. When reorganization advisor presents an application that it is not provided help during supervisory actions or is not given information needed by the entrepreneur. (i.e. $\$ 51(1)((5)))$

6. When entrepreneur applies for it. (i.e. $\$ 51(1)((6)))$

7. When bankruptcy of entrepreneur is declared. (i.e. \$51(1)((7)))

\section{Empirical analysis of failed firm reorganizations}

\subsection{Data and methods for analysis}

Two types of data are needed for current analysis. Firstly, reorganization failure reasons are given in court judgments and therefore judgments concerning reorganization cases must be downloaded from court databases. As authors do not have a list of reorganization cases and therefore different keywords have to be used when searching the database of court judgments (i.e. KIS) ${ }^{2}$. As several proceedings have not ended, many court judgments are not publicly available and search using different keywords might not be with highest efficiency, authors could download 78 court judgments about reorganization proceedings in spring 2012 from KIS.

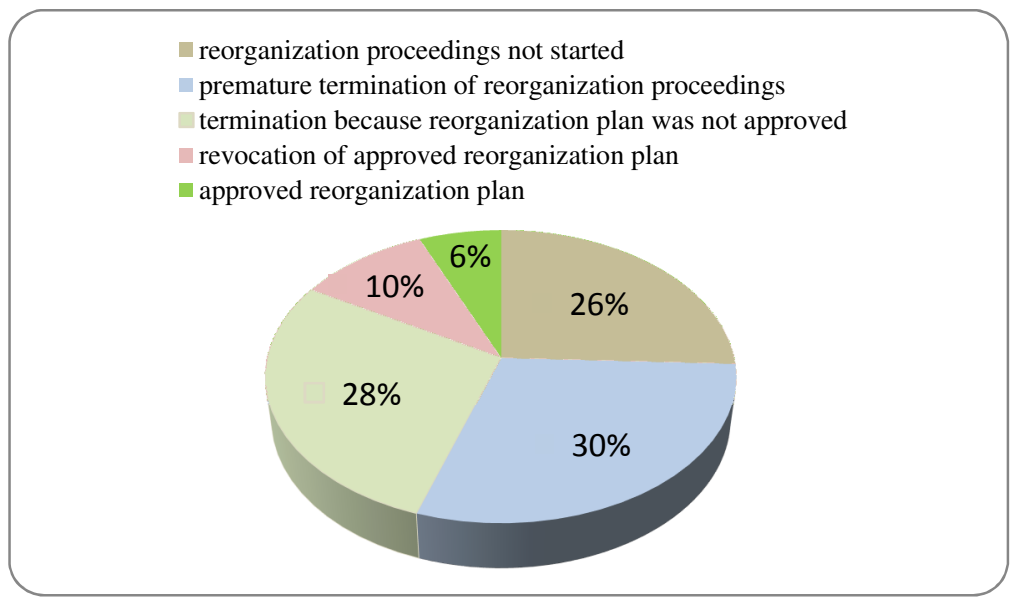

Figure 1. Cases ( $\mathrm{n}=78)$ for analysis and their shares (compiled by authors).

Figure 1 outlines the cases available for analysis. Out of 78 court judgments, in case of 58 reorganization process was started and for 20 it was not due to different reasons. The 58 cases in turn include only 5 firms in case of which reorganization was successful, i.e. when data is collected the firms still follow the approved plans. Still, it does not guarantee that at some point in the future some of them fail to meet the plan and bankruptcy option becomes topical. It can be seen that for 53 cases the

${ }^{2}$ KIS, i.e. Kohtute infosüsteem - Data system of courts. 
reorganization proceedings were terminated because of three reasons: premature termination of reorganization proceedings ( 23 cases), termination because of the non-approval of reorganization plan (22 cases) and revocation of approved reorganization plan (8 cases). The analysis in chapter 3.2 and 3.3 will apply 58 cases outlined previously, as the cases where proceedings were not opened are mostly firms that are already permanently insolvent.

The industries of given firms vary, as the most represented are construction and real estate activities (18 cases for both), followed by manufacturing ( 9 cases) and sales ( 8 cases). The remaining 25 cases are mixed over various other industries not mentioned earlier. The empirical study with cases is qualitative, namely the legal reasons of reorganization failure will be extracted by reading through all the cases available for analysis. Although it would be interesting to know the underlying causes in some cases, e.g. why firms failed to follow approved reorganization plan, then such information is normally not given in court judgments (at least partially because ERA does not require it) and it would demand additional interviews with stakeholders (reorganization advisor and firm's management). Figure 2 shows failed reorganization cases by the time which it takes for the negative event to happen. The results have been generalized, using mainly the terms set by law, and no specific durations have been calculated using the court judgments.

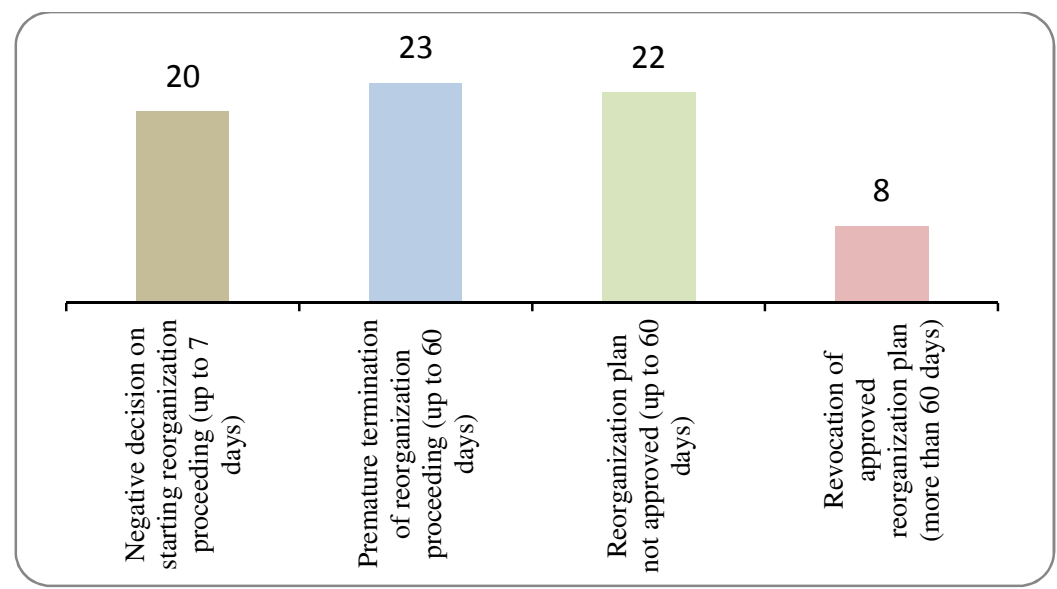

Figure 2. Failure of 73 reorganizations with time till the event (compiled by authors).

The other set of information includes financial data of given firms. For those purposes firms' register codes had to be extracted based on the information in judgments, which in some cases was challenging as the code was not disclosed (but still based on other information in judgment it could finally be disclosed). When the identities of firms were known, pre-reorganization financial data was obtained from Estonian Commercial Register (ECR). The financial data was used to calculate prereorganization financial ratios reflecting three different financial domains: solvency, 
profitability and capital structure. The ratios describing those three domains were selected based on literature and they are in full and abbreviated form listed in Table 1. Financial variables will be calculated for three years, namely to represent the financial situation in the year before reorganization year, but also two and three years before reorganization year. To denote ratios of specific years, subscripts $1,2,3$ will be applied to represent given years in the sequence outlined previously. On the same principle the number of workers will be presented (noted as workers).

Table 1. Financial variables in analysis.

\begin{tabular}{|l|l|}
\hline Domain & Variables \\
\hline Solvency & , i.e. $\frac{C A}{C L}$ \\
\hline Profitability & $\frac{\text { Cash }}{\text { Current liabilities }, \text { i.e. } \frac{C}{C L}}$ \\
\hline Capital structure & $\frac{\text { Net income }}{\text { Net sales }}$, i.e. $\frac{N I}{S}$ \\
\hline Source & $\frac{\text { Total liabilities }}{\text { Total assets }}$, i.e. $\frac{L}{A}$ \\
\hline
\end{tabular}

Source: compiled by authors.

For statistical analysis purposes the studied 58 cases will be classified in two different ways. Classification 1 divides the dataset in two - cases where reorganization was successful (i.e. reorganization plan was accepted, 12 cases, noted as Group 1) and where it was not (46 cases, noted as Group 2), without considering the fact what happened after reorganization plan approval. Classification 2 divides the dataset also in two - firms that finally survived $(5$ cases, which are all active firms on 1.02.2013, noted as Group 1) and all others (i.e. finally failed firms, 53 cases, noted as Group 2). So given classifications represent two different aspects, i.e. successful reorganization and final survival of firms under reorganization. For the comparison of groups created using two given classifications, independent samples median test (ISMT) will be used. The ISMT views, whether there is at least one sample among $k$ samples, that has different median than others (i.e. $\mathrm{H}_{0}: \Theta_{0}=\Theta_{1}=$ $\Theta_{2}=\ldots=\Theta_{k} ; H_{1}$ : the median of at least one population is different). $\mathrm{H}_{1}$ will be accepted when asymptotic significance of the test is $<0.05$ and significance will be denoted in following tables as "Sig.". A limitation of conducting the test is that for Classification 2 one group includes very small number of cases $(n=5)$, which might impact the test statistic.

\subsection{Failure reasons from court judgments}

Figure 3 shows the specific reasons why the started reorganization procedure came to an end without successful reorganization of a firm. It can be seen, that endings are dominated by two highly represented reasons $(\S 39(2)((7))$ and $\S 39(2)((9)))$ which mean that precondition for reorganization lapses (i.e. entrepreneur presents application to end the proceeding or firm has become permanently insolvent) or entrepreneurs do not submit reorganization plan to court. Although in some cases the time for plan composition might be too short for entrepreneurs, this does not prevent them from submitting all documents that have been composed so far. So the 
majority of cases (i.e. 28 from 53) already point to the fact that firms are not suitable for reorganization due to poor financial situation or inability to provide a plan that would show how the firm would remain vital. All other reasons presented can be divided to two groups by representation: causes with average representation (6 different causes having representation of 3-4 times each) and causes with very low, if not to say incidental representation ( 3 different causes having representation of 1 time each).

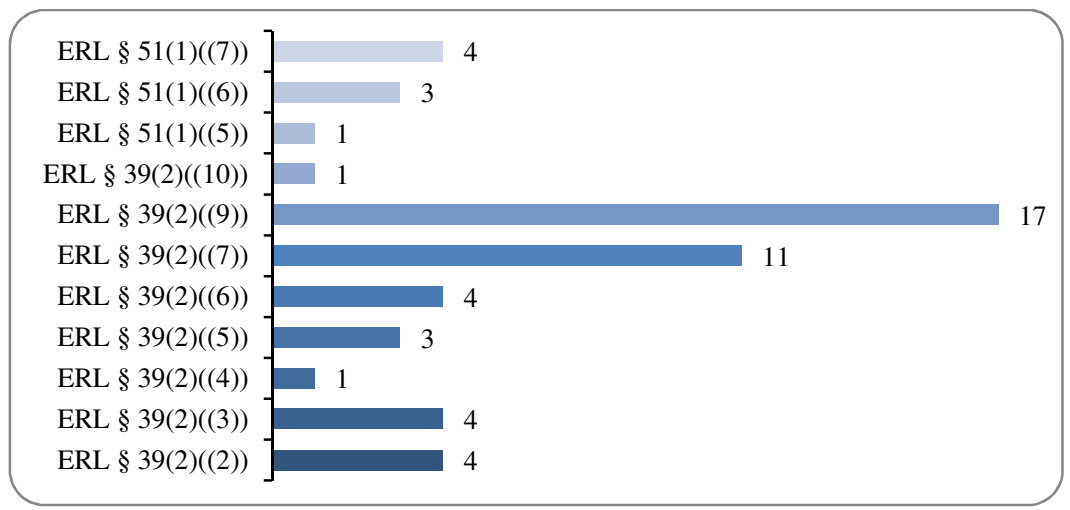

Figure 3. Specific reasons of reorganization proceedings termination for 53 firms using causes given in Chapter 2 of the article (compiled by authors).

The results closely follow which has been noted in literature given in Chapter 1 of the article, namely reorganization failure can be attributed to the cause that firms are just not suitable for reorganization, i.e. they are already insolvent or unable to prove how they can remain vital in the future.

\subsection{Financial characteristics}

Table 2 shows median values of financial variables within groups for two classifications and in the whole dataset. In addition, for both classifications ISMT significance values have been brought out when medians of two groups inside each classification are compared. All ISMT values are insignificant, so the hypothesis of different median values of the financial ratios is rejected in case of all variables for both classifications. It must be noted, that as in case of many variables the number of observations in Group 1 for both classifications becomes very small due to missing cases ${ }^{3}$, then ISMT test applying Yates' correction becomes not significant at 0.05 level. The values in Table 2 are presented without Yates' correction. Yates' correction helps to avoid overestimation when the number of cases is very small, but there is also a threat of overcorrection.

\footnotetext{
${ }^{3}$ Financial data is available for less cases when compared to the available data stated in Chapter 3.1.
} 
Table 2. Median values for (mostly financial) variables through successful (Group 1) and unsuccessful (Group 2) reorganizations using two classifications given in Chapter 3.1 of the article (compiled by authors).

\begin{tabular}{|c|c|c|c|c|c|c|c|}
\hline Variable & \multicolumn{3}{|c|}{ Classification 1} & \multicolumn{3}{|c|}{ Classification 2} & \multirow{2}{*}{$\begin{array}{c}\text { All } \\
\text { cases }\end{array}$} \\
\hline & Group 1 & Group 2 & Sig. & Group 1 & Group 2 & Sig. & \\
\hline Workers $_{1}$ & 38 & 45 & 1.000 & 35 & 60 & 1.000 & 38 \\
\hline Workers $_{2}$ & 48 & 40 & 0.408 & 46 & 41 & 0.589 & 42 \\
\hline Workers $_{3}$ & 43.5 & 35 & 0.485 & 34 & 40 & 0.631 & 39.5 \\
\hline$\frac{L_{1}}{A_{1}}$ & 0.73 & 0.87 & 0.097 & 0.78 & 0.84 & 1.000 & 0.81 \\
\hline$\frac{L_{2}}{A_{2}}$ & 0.73 & 0.78 & 0.728 & 0.73 & 0.77 & 0.635 & 0.77 \\
\hline$\frac{L_{3}}{A_{3}}$ & 0.63 & 0.70 & $0.042 *$ & 0.64 & 0.67 & 0.635 & 0.67 \\
\hline$\frac{N I_{1}}{S_{1}}$ & -0.04 & -0.18 & 0.111 & -0.02 & -0.09 & 0.645 & -0.09 \\
\hline$\frac{N I_{2}}{S_{2}}$ & 0.00 & 0.01 & 0.099 & 0.00 & 0.01 & $0.020^{*}$ & 0.00 \\
\hline$\frac{\mathrm{NI}_{3}}{\mathrm{~S}_{3}}$ & 0.01 & 0.04 & $0.050 *$ & -0.02 & 0.03 & 0.169 & 0.03 \\
\hline$\frac{C A_{1}}{C L_{1}}$ & 0.83 & 0.54 & 0.688 & 0.20 & 0.63 & 0.322 & 0.61 \\
\hline$\frac{C A_{2}}{C L_{2}}$ & 0.80 & 0.93 & 0.728 & 0.60 & 0.94 & 0.154 & 0.90 \\
\hline$\frac{C A_{3}}{C L_{3}}$ & 0.90 & 1.17 & 0.498 & 0.60 & 1.20 & 0.154 & 1.02 \\
\hline$\frac{C_{1}}{C L_{1}}$ & 0.01 & 0.01 & 0.226 & 0.01 & 0.01 & 0.645 & 0.01 \\
\hline$\frac{C_{2}}{C L_{2}}$ & 0.02 & 0.02 & 0.795 & 0.02 & 0.02 & 0.674 & 0.02 \\
\hline$\frac{C_{3}}{C L_{3}}$ & 0.03 & 0.02 & 0.146 & 0.03 & 0.02 & 0.138 & 0.02 \\
\hline
\end{tabular}

* Significance rose over 0.05 level after application of Yates' correction.

Note: after application of Yates' correction all results are insignificant at 0.05 level.

Although the median values are not significantly different, they do not equal with each other and general tendencies can therefore be commented. In case of both classifications unsuccessful reorganizations are characterized with higher leverage and leverage has increased more sharply in time. In case of both classifications firms in two groups eventually become not profitable (negative $\frac{N I}{S}$ ), but it is interesting that successfully reorganized firms in case of classification 2 are unprofitable on the third year before reorganization. Still, through all three years their profitability varies around zero, which supports the fact that given firms have submitted reorganization applications at right time, i.e. when problems have not yet emerged 
dramatically. The immediate payment readiness reflected by $\frac{C}{C L}$ ratio has been very low for all three years, being almost the same for firms in both groups for specific years viewed. This would indicate high probability of solvency problems for all firms in analysis. Interestingly, the other solvency measure $\frac{C A}{C L}$, which reflects the ability to cover liabilities maturing within an year with current assets, is worse for successfully reorganized firms for all years in Classification 2 and in case of Classification 1 only for the first year before reorganization year the group of firms where plan was successfully approved has higher value when compared to failed ones. This shows some controversy when compared to previous results in literature, which have indicated that troubled, but finally surviving firms witness higher solvency when compared to eventually failing firms (see e.g. Lukason 2013). This could be connected to the idea of different failure processes (see Laitinen 1991) and among unsuccessfully reorganized firms there are evidently more acute failure firms, in case of which financial situation worsens very quickly.

\section{Conclusions and implications}

Current article focused on the causes of failed reorganizations among Estonian firms. Previous studies have indicated that an important cause of reorganization failure can be the unsuitability (permanent insolvency or inability to prove firm's future vitality) of firms for reorganization. Also, practice from different legal environments shows a relatively small share of successful reorganizations from both, total reorganization petitions and especially from total firm insolvencies. The Estonian figures from previous years have supported such tendency.

The dataset for current article consisted of 78 court judgments about firm reorganizations, out of which there were 20 cases when reorganization was not started, 53 cases when it was unsuccessful and 5 cases of successful reorganizations. The legal causes of reorganization failure are directly based on the Estonian Reorganization Law, whereas dominantly reorganization fails because of two causes: entrepreneurs do not submit reorganization plan to court or precondition for reorganization lapses (i.e. entrepreneurs present application to end the proceeding or firm has become permanently insolvent).

In two different classifications (in the first successful reorganizations are firms for which reorganization plans are approved and in the second they are firms which eventually remain vital), the financial ratios of successfully and unsuccessfully reorganized firms are compared. None of the studied financial ratios is significantly different through two groups. Still, for firms where reorganization was unsuccessful the values tend to be better two and three years before the reorganization year, whereas the contrary tendency occurs on a year before reorganization year.

As according to the analysis most firms fail at an early stage of reorganization, then before starting reorganization proceedings the vitality of firms should be prescreened in more detail in order to avoid permanently insolvent firms from entering the procedure. The article can be developed in many ways, for instance by 
introducing larger dataset and using additional documents from courts to study the causes of unsuccessful reorganizations in more detail.

\section{References}

1. Bankruptcy and a Fresh Start: Stigma on Failure and Legal Consequences of Bankruptcy. (2002) Brussels: Philippe and Partners, Deloitte and Touche Corporate Finance, 428 p.

2. Barker III, V.L., Duhaime, I.M. Startegic Change in the Turnaround Process: Theory and Empirical Evidence. Strategic Management Journal, Vol. 18, No. 1, pp. 13-38.

3. Brouwer, M. (2006) Reorganization in US and European Bankruptcy Law. European Journal of Law and Economics, Vol. 22, No. 1, pp. 5-20.

4. Chowdhury, S.D. (2002) Turnarounds: A stage theory perspective. Canadian Journal of Administrative Sciences, Vol. 19, No. 3, pp. 249-266.

5. Claessens, S., Klapper, L.F. (2005) Bankruptcy around the World: Explanations of its Relative Use. American Law and Economics Review, Vol. 7, No. 1, pp. 253-283.

6. Couwenberg, O. (2001) Survival Rates in Bankruptcy Systems: Overlooking the Evidence. European Journal of Law and Economics, Vol. 12, No. 3, pp. 253273.

7. Davydenko, S.A., Franks, J.R. (2008) Do bankruptcy codes matter? A study of defaults in France, Germany and the UK. Journal of Finance, Vol. 63, No. 2, pp. 565-608.

8. Djankov, S., Hart, O., McLiesh, C., Shleifer, A. (2008) Debt Enforcement around the World. Journal of Political Economy, Vol. 116, No. 6, pp. 11051150 .

9. Franks, J.R., Nyborg, K.G., Torous, W.N. (1996) A comparison of US, UK and German insolvency codes. Financial Management, Vol. 25, No. 3, pp. 86101.

10. I ja II astme kohtute statistilised menetlusandmed, 2009. aasta kokkuvõte [First and second instance court proceeding data, year 2009 summary]. (2010) Tallinn: Justiitsministeerium [Ministry of Justice], 34 p.

11. Kaiser, K.M.J. (1996) European bankruptcy laws: Implications for corporation facing financial distress. Financial Management, Vol. 25, No. 3, pp. 67-85.

12. Kärkinen, E.-L. (2010) Taxonomy of six explanatory reorganization interruption patterns: empirical evidence from the Finnish firms, June 2008 May 2009. International Journal of Management and Enterprise Development, Vol. 9, No. 3, pp. 276-291.

13. Laitinen, E.K. (1991) Financial ratios and different failure processes. Journal of Business, Finance and Accounting, Vol. 18, No. 5, pp. 649-673.

14. Laitinen, E.K. (2009) Success factors in small firm reorganization. International Journal of Management and Enterprise Development, Vol. 6, No. 3, pp. 300321. 
15. Laitinen, E.K. (2011) Assessing viability of Finnish reorganization and bankruptcy firms. European Journal of Law and Economics, Vol. 31, No. 2, pp. 167-198.

16. Lopez Gutierrez, C., Garcia Olalla, M., Torre Olmo, B. (2011) Economic valuation of the efficiency of bankruptcy systems. Spanish Journal of Finance and Accounting, Vol. 40, No. 150, pp. 221-250.

17. Lukason, O. (2010) Maksejõuetuse põhjuste analüüs [Analysis of insolvency reasons]. Tallinn: Justiitsinsiteerium [Ministry of Justice], $38 \mathrm{p}$.

18. Lukason, O. (2012) Financial Performance Before Failure: Do Different Firms Go Bankrupt Differently? International Journal of Trade, Economics and Finance, Vol. 3, No. 4, pp. 305-310.

19. Lukason, O. (2013) What distinguishes survivors from failures among defaulted firms? Actual Problems of Economics (forthcoming in 2013).

20. Pankrotiseadus [Estonian Bankruptcy Act]. [https://www.riigiteataja.ee/akt/129062011014]. Retrieved 10.02.2013.

21. Poston, K.M., Harmon, W.K., Gramlich, J.D. (1994) A test of financial ratios as predictors of turnaround versus failure among financially distressed firms. Journal of Applied Business Research, Vol. 10, No. 1, pp. 41-56.

22. Saneerimisseadus [Estonian Reorganization Law]. [https://www.riigiteataja.ee/akt/125042012007]. Retrieved 10.02.2013.

23. Sheppard, J.P., Chowdhury, S.D. (2005) Riding the Wrong Wave: Organizational Failure as Failed Turnaround. Long Range Planning, Vol. 38, No. 3, pp. 239-260.

24. Sudarsanam, S., Lai, J. (2001) Corporate Financial Distress and Turnaround Strategies: An Empirical Analysis. British Journal of Management, Vol. 12, No. 3, pp. 183-199.

25. Vutt, M. (2011) Saneerimiskava kinnitamise praktika [Practice of reorganization plan approval.]. Tartu: Riigikohus [The Supreme Court of Estonia], 22 p.

26. Wang, C.-A. (2012) Determinants of the Choice of Formal Bankruptcy Procedure: An International Comparison of Reorganization and Liquidation. Emerging Markets Finance and Trade, Vol. 48, No. 2, pp. 4-28.

27. White, M. (1989) The Corporate Bankruptcy Decision. Journal of Economic Perspectives, Vol. 3, No. 2, pp. 129-151.

28. Äriseadustik [Estonian Business Code]. [https://www.riigiteataja.ee/akt/118122012008]. Retrieved 10.02.2013. 


\title{
SANEERIMISMENETLUSE EBAÕNNESTUMISE PÕHJUSED EESTIS
}

\author{
Oliver Lukason, Artjom Urbanik \\ Taru Ülikool
}

\section{Sissejuhatus}

Tagamaks ajutiselt raskustesse sattunud, kuid muidu elujõuliste ettevõtete turule jäämise, sisaldavad enamike riikide maksejõuetusmenetlused saneerimise võimalust. Eestis võeti saneerimisseadus vastu 2008. aasta lõpus ning enne seda oli saneerimine võimalik pankrotiseaduse vahendusel. Vaatamata saneerimisseaduse kehtima hakkamisele on edukalt saneeritud ettevõtete hulk Eestis olnud väike. Näiteks 2009. aastal kuulutati välja 1562 ettevõtte pankrot ning saneerimisavalduse esitas 93 ettevõtet, kusjuures kinnitatud saneerimiskavasid oli ainut 6 tükki. Eelnevast tulenevalt on artikli eesmärgiks välja selgitada, millised on olnud ettevõtete saneerimismenetluse ebaõnnestumise põhjused Eestis. Vaatluse all on nii saneerimismenetluse seadusest tulenevad ebaõnnestumise põhjused kui ka edukalt ja ebaedukalt saneeritud ettevõtete saneerimiseelsed finantsnäitajad.

\section{Varasemad saneerimise teemalised uuringud}

Viimase paarikümne aasta jooksul on saneerimise teemal teostatud rohkelt uuringuid, kusjuures täheldatav on ka oluline variatsioon käsitletavate teemade osas. Saneerimismenetluse tulemuslikkust käsitlevad uuringud viitavad edukate saneerimiste vähesusele, kusjuures Ameerika Ühendriikide menetluse (Chapter 11) tulemuslikkus on Kontinentaal-Euroopa omast oluliselt kõrgem (Couwenberg 2001, Brouwer 2006). Samas peab menetluse tulemuslikkust hindavate uuringute puhul silmas pidama, kuidas on täpselt defineeritud edukas saneerimine (näiteks kas kava kinnitamine, kava täitmine või ettevõtte tegutsema jäämine peale kava täitmist). Laiemas plaanis määrab saneerimise edukuse ka õiguskeskkonna võlglase- või võlausaldajakesksus, kusjuures Kontinentaal-Euroopa õiguskeskkondasid peetakse pigem võlausaldaja sõbralikeks (Franks et al. 1996, Lopez Gutierrez et al. 2011).

Juhtimisteoorias seostatakse ebaedukat saneerimist ebaõnnestunud muudatustega ettevõtte tegevuses (ing. k. turnaround) (Chowdhury 2002, Sheppard and Chowdhury 2005). Täpsemalt võivad kerkida probleemid seoses muudatuste ajastusega ning muudatuste liigse fokuseerimisega operatiivsetele, mitte hädavajalikele strateegilistele muudatustele (Chowdhury 2002, Sudarsanam and Lai 2001, Barker III and Duhaime 1997). Mitmed uuringud vaatlevad ka ettevõtete saneerimiskõlbulikkust läbi varasemate finantsnäitajate. Laitinen (2011) leidis, et enamik saneerimismenetluses olevatest ettevõtetest on elujõuetud. Uuringutes on ka leitud, et edukaid ning ebaedukaid saneerimisi ei ole varasemate finantsnäitajate põhjal võimalik tuvastada (Poston et al. 1994, Laitinen 2009). Ettevõtete finantsnäitajate põhjal on võimalik välja tuua erinevad ebaõnnestunud saneerimise mustrid, kuid ettevõtete vahelistele erisustele vaatamata on iga ebaõnnestunud saneerimist iseloomustav mõnede finantsnäitajate väga kehv tase (Kärkinen 2010). 


\section{Eesti saneerimisseadus ja ebaedukas saneerimine}

Eesti saneerimisseadus (SanS) jõustus 26.12.2008 ning vastava seaduse alusel on saneerimise ebaõnnestumine võimalik kolmel erineval ajahetkel, täpsemalt saneerimismenetluse algatamata jätmine, pärast saneerimismenetluse algatamist või saneerimiskava kinnitamise järgselt.

Vastavalt SanS §8 algatab kohus saneerimismenetluse kui saneerimisavaldus vastab tsiviilkohtumenetluse seadustikus ja SanS esitatud nõuetele ning kui ettevõtja on põhistanud, et: 1) tema maksejõuetuse tekkimine tulevikus on tõenäoline; 2) ettevõte vajab saneerimist; 3) ettevõtte jätkusuutlik majandamine on pärast saneerimist tõenäoliselt võimalik. Sama paragrahv ütleb ka, et saneerimismenetlust ei algatata kui: 1) ettevõtja suhtes on algatatud pankrotimenetlus; 2) on tehtud kohtumäärus ettevõtja sundlõpetamise kohta või toimub täiendav likvideerimine; 3) ettevõtja suhtes toimunud saneerimismenetluse lõppemisest on möödunud vähem kui kaks aastat.

SanS §39 märgib, et saneerimismenetluse võib ennetähtaegselt lõpetada üksnes enne saneerimiskava kinnitamist, täpsemalt järgnevatel põhjustel (\$39 lõige 2 punktid vastavalt nende seaduses toodud numeratsioonile):

1) ettevõtja kaasaaitamiskohustuse rikkumise tõttu;

2) kui ettevõtja jätab tasumata saneerimisnõustaja või eksperdi tasu ja kulutuste katteks kohtu deposiiti kohtu määratud summa;

3) saneerimiskava kinnitamata jätmise tõttu;

4) vastuvõtmata saneerimiskava kinnitamise avalduse rahuldamata jätmisel;

5) vastuvõtmata saneerimiskava kinnitamata jätmisel;

6) ettevõtja avalduse alusel;

7) saneerimismenetluse algatamise eelduste äralangemise korral;

8) ettevõtja vara raiskamise või võlausaldajate huvide kahjustamise korral;

9) saneerimiskava tähtpäevaks esitamata jätmise tõttu;

10) nõude ebaselguse tõttu.

SanS §51 märgib, et kohus tühistab kinnitatud saneerimiskava (s.t. katkestab saneerimise; $\$ 51$ lõige 1 punktid vastavalt nende seaduses toodud numeratsioonile):

1) kui ettevõtja on pärast saneerimiskava kinnitamist tunnistatud süüdi pankroti- või täitemenetluse kuriteos;

2) kui ettevõtja ei täida saneerimiskavast tulenevaid kohustusi olulisel määral;

3) kui saneerimiskava kehtivuse ajast vähemalt poole möödumisel on ilmne, et ettevõtja ei suuda saneerimiskavaga võetud kohustusi täita;

4) saneerimisnõustaja avalduse alusel, kui ei maksta tasu järelevalve teostamise eest;

5) saneerimisnõustaja avalduse alusel, kui ettevõtja ei osuta saneerimisnõustajale abi järelevalvekohustuse täitmisel või ei anna saneerimisnõustajale teavet, mida viimane vajab järelevalve teostamiseks;

6) ettevõtja avalduse alusel;

7) kui kuulutatakse välja ettevõtja pankrot. 


\section{Kasutada olevad andmed}

Saneerimise ebaõnnestumise põhjused tuvastatakse Kohtute Infosüsteemist allalaaditud kohtulahendite põhjal. Kokku oli analüüsi jaoks võimalik kasutada 78 kohtulahendit, mis jagunesid järgnevalt: 20 juhul polnud saneerimismenetlust algatatud, 46 juhul saneerimismenetlus lõpetati enne saneerimiskava kinnitamist, 7 juhul kinnitatud saneerimiskava tühistati ning 5 juhul oli saneerimine edukas (st. analüüsi teostamise hetkel on saneerimiskavad kehtivad). Kohtulahendite põhjal tuvastati ka ettevõtted, mis võimaldas täiendava analüüsi teostamist kasutades ettevõtete saneerimismenetluse eelseid finantsnäitajaid. Iga ettevõtte jaoks arvutati välja neli suhtarvu, mis on alljärgnevas tabelis 1 toodud. Kõik suhtarvud arvutati kolme saneerimismenetluse aastale eelneva aasta kohta ning vastavat aastat märgitakse alltoodud tabelis 2 vastava alaindeksiga (s.t. 1 viitab näiteks saneerimismenetluse aastale eelnevale aastale).

Tabel 1. Analüüsis kasutatud finantssuhtarvud

\begin{tabular}{|l|l|}
\hline Muutujate valdkond & Muutujad \\
\hline Maksevõime & , s.t. $\frac{C A}{C L}$ \\
\hline Kasumlikkus & , s.t. $\frac{C}{C L}$ \\
\hline Kapitali struktuur & $\frac{\text { Puhaskasum }}{M \_ \text {gitulu }}$, s.t. $\frac{N I}{S}$ \\
\hline
\end{tabular}

Allikas: autorite koostatud.

Analüüsi jaoks kasutatakse kahte klassifikatsiooni. Klassifikatsioon 1 jaotab ettevõtted kaheks selle alusel, kas saneerimiskava kinnitati või mitte: kinnitati (Grupp 1 - 12 juhtumit) ja ei kinnitatud (Grupp 2 - 46 juhtumit). Klassifikatsioon 2 jaotab ettevõtted kaheks selle alusel, kas saneerimine oli kokkuvõttes edukas: kehtiv saneerimiskava (Grupp $1-5$ juhtumit) ja saneerimismenetluse ennetähtaegne lõpetamine või kava tühistamine (Grupp 2 - 53 juhtumit).

\section{Analüüsi tulemused ja järeldused}

Joonis 1 näitab 53 ettevõtte lõikes algatatud saneerimismenetluse lõpetamise põhjuseid. Domineerivad kaks põhjust: saneerimismenetluse algatamise eelduste äralangemine $(n=11)$ ja saneerimiskava tähtajaks esitamata jätmine $(n=17)$. 
Tabel 2. Mediaanväärtused kahe klassifikatsiooni gruppide lõikes

\begin{tabular}{|c|c|c|c|c|c|c|c|}
\hline Muutuja & \multicolumn{3}{|c|}{ Klassifikatsioon 1} & \multicolumn{3}{|c|}{ Klassifikatsioon 2} & \multirow{2}{*}{ Kokku } \\
\hline & Grupp 1 & Grupp 2 & $\mathrm{p}$ & Grupp 1 & Grupp 2 & $\mathrm{p}$ & \\
\hline$\frac{L_{1}}{A_{1}}$ & 0,73 & 0,87 & 0,097 & 0,78 & 0,84 & 1,000 & 0,81 \\
\hline$\frac{L_{2}}{A_{2}}$ & 0,73 & 0,78 & 0,728 & 0,73 & 0,77 & 0,635 & 0,77 \\
\hline$\frac{L_{3}}{A_{3}}$ & 0,63 & 0,70 & $0,042 *$ & 0,64 & 0,67 & 0,635 & 0,67 \\
\hline$\frac{N I_{1}}{S_{1}}$ & $-0,04$ & $-0,18$ & 0,111 & $-0,02$ & $-0,09$ & 0,645 & $-0,09$ \\
\hline$\frac{N I_{2}}{S_{2}}$ & 0,00 & 0,01 & 0,099 & 0,00 & 0,01 & $0,020^{*}$ & 0,00 \\
\hline$\frac{\mathrm{NI}_{3}}{\mathrm{~S}_{3}}$ & 0,01 & 0,04 & $0,050 *$ & $-0,02$ & 0,03 & 0,169 & 0,03 \\
\hline$\frac{C A_{1}}{C L_{1}}$ & 0,83 & 0,54 & 0,688 & 0,20 & 0,63 & 0,322 & 0,61 \\
\hline$\frac{C A_{2}}{C L_{2}}$ & 0,80 & 0,93 & 0,728 & 0,60 & 0,94 & 0,154 & 0,90 \\
\hline$\frac{C A_{3}}{C L_{3}}$ & 0,90 & 1,17 & 0,498 & 0,60 & 1,20 & 0,154 & 1,02 \\
\hline$\frac{C_{1}}{C L_{1}}$ & 0,01 & 0,01 & 0,226 & 0,01 & 0,01 & 0,645 & 0,01 \\
\hline$\frac{C_{2}}{C L_{2}}$ & 0,02 & 0,02 & 0,795 & 0,02 & 0,02 & 0,674 & 0,02 \\
\hline$\frac{C_{3}}{C L_{3}}$ & 0,03 & 0,02 & 0,146 & 0,03 & 0,02 & 0,138 & 0,02 \\
\hline
\end{tabular}

* Olulisustõenäosus üle 0,05 pärast Yates'i korrektsiooni, tabelis esialgsed tulemused. Märkus: pärast Yates'i korrektsiooni on kõik tulemused tasemel 0,05 ebaolulised.

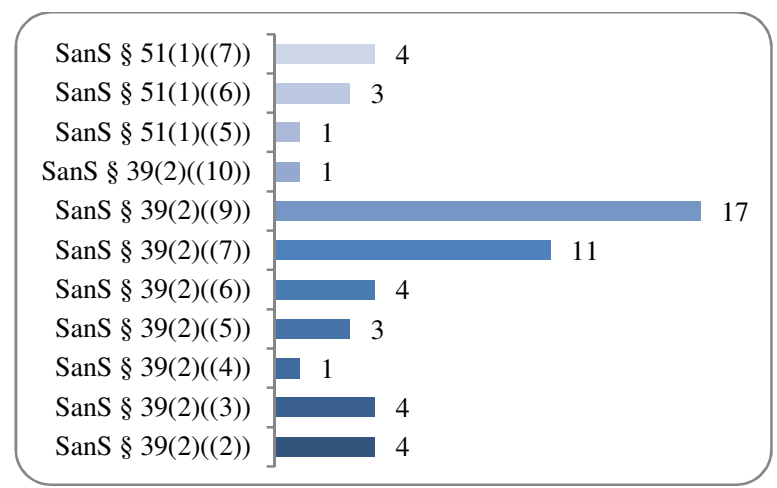

Joonis 1. Saneerimismenetluse lõpetamise põhjused ( $\mathrm{n}=53$ ettevõtet). 
Saneerimise ebaõnnestumise põhjused viitavad selgelt asjaolule, et enamik ettevõtteid on olnud saneerimiseks kõlbmatud. Kahe klassifikatsiooni lõikes edukate ja ebaedukate ettevõtete finantssuhtarvude mediaanväärtuste võrdlus (vt. tabel 1) näitab, et ühelgi juhul pole nende väärtused kahe grupi lõikes statistiliselt oluliselt erinevad ( $p$ väärtused suuremad kui 0,05 peale Yates'i korrektsiooni). Teataval määral võib tulemusi mõjutada edukate grupis olevate ettevõtete väike arv, mida võimendab ka asjaolu, et osadel ettevõtetel pole mõnede aastate finantsandmeid Äriregistrile esitatud. Finantssuhtarvude väärtustest ilmnevad huvitavad asjaolud. Nimelt on ebaedukalt saneeritud ettevõtete puhul saneerimisaastale üleeelneva ning üle-üleeelneva aasta näitajad mitme finantssuhtarvu puhul paremad kui edukalt saneeritute puhul. Saneerimisaastale eelneval aastal on tendents vastupidine ning üldiselt on edukalt saneeritud ettevõtete näitajad paremad. 